\title{
GlobalBritain $^{\mathrm{TM}}$ : The Discursive Construction of Britain's Post-Brexit World Role
}

Oliver Daddow (University of Nottingham)

\section{Address for correspondence:}

Dr Oliver Daddow

Assistant Professor in British Politics and Security

School of Politics and International Relations

University Park

Nottingham

NG7 2RD

Email: oliver.daddow@nottingham.ac.uk 


\title{
GlobalBritain $^{\mathrm{TM}}$ : The Discursive Construction of Britain's Post-Brexit World Role
}

\section{Oliver Daddow}

\begin{abstract}
Of the many dilemmas faced by Theresa May in negotiating Britain's withdrawal from the

$\underline{\text { EU, finding a workable narrative to accompany Brexit proved one of the most intractable. }}$

$\underline{\text { She and her top government ministers alighted on the idea of "Global Britain", unpacked in }}$ this article using qualitative discourse analysis. It begins by positioning the contribution in the literatures on constructivist approaches to British foreign policy. Next, it explains the method used to select the relevant sources, develop the codebook and interpret the data. The third section outlines the policy architecture intended to make GlobalBritain ${ }^{\mathrm{TM}}$ practical reality. The final section unpacks the accompanying "vision" behind GlobalBritain ${ }^{\mathrm{TM}}$, which is framed as the story of Britain escaping a damaging period of confinement inside the EU "prison". The central argument is that GlobalBritain ${ }^{\mathrm{TM}}$ puts a marked Eurosceptic twist on a
\end{abstract} long-standing UK grand strategy aimed at remaining at the top table of global affairs using a pragmatic approach to international relationships. Always a troublesome arena for the conduct of its external relations, Brexit shows Britain continuing its half-in, half-out approach to European integration. The conclusion critically reflects on the research we can now conduct to discover more about this foreign policy narrative in-the-making. Like the politicians, scholars are still puzzled by the "why" and "how" of Brexit. This article contributes to the research on the "how" of Brexit by exploring the Conservative government's foreign poliey vision for Britain's role in the world outside the EU. It first explains the contributions the research makes to constructivist interpretivist foreign policy analysis. Next, it explains the method used to investigate the discursive substance of the GlobalBritain ${ }^{\mathrm{TM}}$ narrative: spatiality, temporality, ethicality and intertextmality. The third 
section outlines the proposed policy architecture of GlobalBritainTM. The final section reperts the findings on the narrative side, showing how the discourse approach yielded comprehensive insights into this vision-in-the-making, bolstered by the politicians' colourfut tuse of metaphor. The central argument is that GlobalBritainTM puts a Conservative Euresceptic twist on long standing British foreign policy traditions, making for a negative, defensive narrative that will likely limit its resenance to key stakeholders domestically and internationally. The conclusions reflect on the utility of using this method to connect discourse analysts and foreign policy analysts and, thereby, its potential to impact on the policy community by mainstreaming discourse analysis as a toolkit for conducting foreign pelicyevaluation.

\section{Keywords}

Brexit; discourse analysis; British foreign policy; Global Britain; narrative; Theresa May

Word count: 7,9767,979 


\section{Introduction}

\section{$\underline{\text { So, is there any substance to the claim that GlobalBritain }}$ TM is a meaningful "turning}

point in our nation's story" (Davis, 2016) - and how can we find out? Attacking

GlobalBritain ${ }^{\mathrm{TM}}$ was, and will continue to be, another device for contesting Brexit. elites use epideictic rhetoric (umpacked in the methods section below) to generate and legitimise foreign policy narratives "through which they seek seeking "to wnite the citizenry around a set of shared ideals and a common identity" (Atkins, 2015, pp. 603 605). Although this is understandable in such a febrile political climate, it is also unfortunate because

GlobalBritain ${ }^{\mathrm{TM}}$ provides a fascinating insight into how

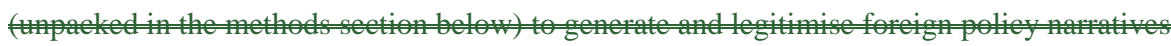
"through which they seek to unite the citizenry around a set of shared ideals and a common identity" (Atkins, 2015, pp. 603-605).Finding answers to these questions is no simple task for two reasons. First, at the time of writing, GlobalBritainTM is happening but has not yet happened: it is "under construction", literally and metaphorically, meaning that the eonstellation of material practices that will give concrete expression to the vision (such as trade deals and security agreements) have not yet been agreed or implemented. Second, lasting innovation in UK foreign policy is difficult to achieve, whether born of ideologicat choice (on New Labour's “ethical dimension” see Little and Wickham-Jones 2000; Wheeler and Dunne, 2002; Daddow, 2011), or the exigencies of internal government management (on the 20102015 Coalition government's "liberal Conservatism" (Beech, 2011; Clarke, 2015; Daddow and Schnapper, 2013; Daddow, 2015a). These governments have left important 
legacies on the ground, but less of a mark on Britain's pest 1945 grand strategy, including an iit is high time that we step away from the heat of controversy and-shine a light on what more informed debate about GlobalBritain ${ }^{\mathrm{TM}}$ andBrexit and the future of British foreign this article is to shine that light usingt. According to this broad scholarly consensus, the consider assessing the shape of the contours of the vision it lays down for Britain's foreign Brexit (May, 2017a). The opening section grounds roetsexplains-the article's contribution foreign policy analysis and the study of British foreign policy. The second section explains the rationale for treating the subject matter discursively (Milliken, 1999) and the method of theory of where Brexit decision making lay in theof European policy decision-making in Section three outlines GlobalBritain ${ }^{\mathrm{TM}}$ 's policy architecture using a four-pillar framework incorporating the mutually reinforcing instruments of its-hard power - military, diplomatic $\underline{\text { economic }}$ - and soft power - the power to attract (Hill and Beadle, 2014) and persuade other states to the rightness of one's national goals_power dimensions_hard and soft power are 2008); applied to the study of British foreign policy in Daddow, 2015a.; $)$. The final section audiences of the appropriateness of the journey on which Britain has embarked through Brexitfashion their into a story about the purpose and direction of Britain's travel on leaving

The prime argument belowcentral claim in what follows is that the policy architecture of GlobalBritain ${ }^{\mathrm{TM}}$ puts a Conservative Eurosceptic twist on long-standing British foreign policy traditions. The policy architecture is firmly in line with the "pragmatic" foreign policy tradition since 1945 (Honeyman, 2017) in British foreign policy since 194, aimed at promoting British prosperity, guaranteeing its security, 5 and keeping Britain at the "top table" of global affairs through the careful calibration of its international relationships and institutional collaborations (Bratberg, 2011)-(see above). Against this backdrop, Brexit has been packaged as a change of tactic in pursuit of a familiar grand strategy.-More novelty is evident on the narrative side, with GlobalBritain ${ }^{\mathrm{TM}}$ discourse -casting Britain as a captive 
making a "great escape" from the EU "prison" (Rankin, 2018; Staunton, 2018). The variously, been described as a story of "redemption from the European venture" (Kenny and Pearce, 2018, p. 105), a former great power seeking "lost status" outside the EU (see Beaumont, 2017, pp. 385-387) and a an "escaping prisoner", wrapped up in the Conservative after it had been subjugated by an empire" (von Bismarck, 2017). The article concludes by critically reflecting on and a former great power seeking "lost status" outside the EU (see policy narrative in-the-making.- In a nutshell, May's government has constructed Britain as a

Interpreting Foreign Policy Narratives: A Diseourse Appreach

Constructivists (see Bevir and Daddow, 2015) theorize foreign policy as a social activity with meaning-making at its heart (applied to the UK in Gaskarth, 2013). These meanings underpin and are given practical expression by foreign policy practices. Narratives are, therefore, widely considered to be vital to the process of defining Britain's role in the world (see McCourt, 2014; Blagden, 2017; Blagden, 2018), but they are often explored-welt after the event_, or treated as historical curiosities. It is rare to see narrative analysis applied contemporaneously at the policy development stage to untangle vision-ideas literally and metaphorically as they are in the procesunder constructions of informing controversial or eontested policy goals such as Brexit. Whilst this potentially leaves hostages to fortune, it also provides ways for academics to impact upon debates by providing richly contextual, systematically derived empiricalcontext sensitive evidence from a morass of eften confusing text data, little of which usually makes it to the public domain, beyond the odd soundbite (Broad and Daddow, 2010). The articleft finds much to commend Knud Erik Jørgensen’s (2015) opinion, therefore, that there is still much potential formuch value in cross- 
fertilizingation between discourse theoryerists en the one hand-and foreign policy analysists

\section{Method}

But if we wish to interpret GlobalBritainTM as a foreign policy narrative, how dowe do it discourse method for research adapted the disceurse metheinterpreting British European approach to identifying and analysing the relevant qualitative data.dexplieated by Tode

\section{Step 1: Which texts?}

Not being "inside" the policy making process andObserving things as an "outsider",-, on $\underline{\text { meant - means that we-havinge to work with publicly available knowledge about how Brexit }}$ and who "authored" the main contours of the strategic communications. Most credible during her long stint running the Home Office (May 2010 to July 2016), May ran a "closed", non-inclusive decision-making eentralized-operation (Pickard and Mance, 2017): "she does not care to share power any more than is necessary" (Usherwood, 2017).

$\underline{\text { small, dedicated team" (Mohdin, 2018) -puts Mayher in line with many a previous UK prime }}$ $\underline{\text { minister confronted with "wicked" foreign and/or European policy dilemmas (Daddow, }}$

\section{1).}

the Cabinet Office (Casalicchio and Rutter, 2018), side-lining even supposedly heavyweight departments such as the FCO. the Cabinet Office and Downing Street (Casalicehio and Rutter, 2018). We can fairly assume that the same has been true, to varying degrees, for the other main government departments. The exigency of policy management by and from the eentre became more obvious-May's grip over Brexit policy tightened as the withdrawal negotiations proceeded and fractures inside government began to appear (Kirby, 2018). For instance, at the time of writing DxEU had been led by three ministers: David Davis (July 


\section{6-July 2018), Dominic Raab (July 2018-November 2018) and Stephen Barclay}

(November 2018-present), the first two resigning citing an overbearing Downing Street operation,

Using this theory of how Brexit policy was made, the decision was made to focus on May and her top team in the formative early years of Brexit when the GlobalBritain ${ }^{\mathrm{TM}}$ script was being authored. It takes the story from July 2016 to a neat cut-off in July 2018, when Boris Johnson resigned from the FCO, hours after Davis left the DxEU. In effect, this was the first "wave" of GlobalBritain ${ }^{\mathrm{TM}}$ discourse: designing the strategy and establishing the essentials of the vision. In the same period Jeremy Hunt replaced Boris Johnsen in July 2018. tracking how successful its proponents were in establishing its legitimacy in the minds of key stakeholders Nevertheless, by setting out the discourse terrain the article can be used as a toø1 of policy evaluation, as described in the conclusion. Table 1 sets out the main primary documentssources used to interpret GlobalBritain ${ }^{\mathrm{TM}}$. Reflecting the power structures described above, the focus is on May, aided and abetted in the erucial formative early months of Brexit by high profile figures from the Leave campaign, notably Boris Johnsen at the Foreign Office, Liam Fox at the newly created Department for International Trade and David Davis at another newly created ministry, the Department for Exiting the European Union (DxEU). The core material is fleshed out with the words of other ministers such as Priti Patel (July 2016 November 2017) and Penny Mordaunt (November 2017 present) at the Department for International Development's Downing Street operation, with the concentric circles of influence emanating out to the FCO, DxEU, Department of International Trade and DfID, thence to the diplomatic operation abroad (the latter not covered here).. At the core are speeches on Brexit, British foreign and European policy delivered by the key members of May into economic practice through free trade deals and so on's foreign policy team. Then, there is an array $\theta$ This data is complemented by reports plus these frem think tank 
decuments fromfrom published by right leaning think tanks known to have close (see for example O'Murchu and Mance, 2017). which we use to understand more about the to sketchgenerate a picture of where, beyond Westminster, GlobalBritain ${ }^{\mathrm{TM}}$ was being and marketed. However, a full analysis of think-tanks and the production of GlobalBritain ${ }^{\mathrm{TM}}$ discourse will have to wait for another day.deliberated and advocated. Between them, the

\section{Step 2: Reading, analysing and reporting the Text Datathe text data}

This is not a content analysis of GlobalBritain ${ }^{\mathrm{TM}}$, concerned only or mainly with what was said and how oftenabout it, but a discourse analysis of how propositions are expressed $;$ which foregrounds how "propositions are expressed, "on the basis that the linguistic choices [speakers] make are crucial for an analysis of what the text communicates" (Cameron and Panović, 2014, p. 67). The research questions driving the coding process were: (i) What was the proposed policy content of GlobalBritain ${ }^{\mathrm{TM}}$ ? (ii) How did GlobalBritain ${ }^{\mathrm{TM}}$ advocates explain, and-justify and thereby mobilize support for this vision for British foreign policy $\underline{\underline{\text { after Brexit? In line with established discourse methodology (Wetherell et al., 2009, p. 39), }}}$, the research questions were answered by categorizsing and coding the text data to elicit the $\underline{\text { relevant keywords. In tightly controlled political messaging there is often frequent repetition }}$ within a politician's oeuvre (temporally), as well as across speeches by different politicians at the same "moments" (spatially), making the keywords relatively easy to identify from a core corpus of texts, as described below. The keywords signal what is important to a given speaker and/or set of speakers and are used to work up a picture of the linguistic "hooks" on which the discourse hangs.

, plus in tightly controlled political messaging there is often frequent repetition within that stays as faithful as possible to what the speakers appear to have wanted to convey by their words. By "piling up" quotations from the speakers on each of the themes sparked by 
the research questions (policy content and "vision", respectively) one can write a richly detailed account of what we think the speakers were getting at in phrasing things as they did,

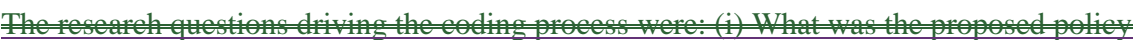

foreign policy aspirations in several of the speeches and there was also a strong path dependency to the discourse. The script did not change much over the years 2016 to 2018. in any discernible way over identify from a surface reading. For exampleHelpfully, May's January 2017 Lancaster House speech (May, 2017a) included a section halfway through

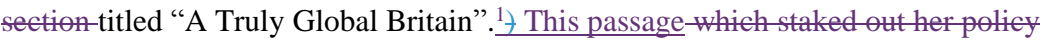
aspirations became the agreed "script" for describing Britain's preferred foreign policy architecturepreferences post-Brexit, meaning the codebook on policy architecture was built around-eoding for words relating to hard and soft power, especially trade, the economy, security, science and innovation.. The rest of the speeches showed that neither May nor her ministers deviated from this initial template in any significant way. I am confident, therefore, 
that the four pillar framework for interpreting the policy horizons of GlobalBritainTM, set out

Getting at the narrative and "vision" components identity strand of GlobalBritain"M discourse required a more nuanced reading of the material, necessitating attention to the epideictic rhetoric through which foreign policy elites consolidate national community identity through exclusions and attention to the differentiations drawn in the texts between what social psychologists call-what secial psychelegists call "in-groups" and "out-groups"

(Beaumont, 2017, p. 380), or , and what political scientists refer to as the national "Self" and international "Others"- (Atkins, 2015, p. 605; Jørgensen, 2015, p. 501). In British European foreign policy discourse this antithesis has tended to surface_, histerically, in tales of an "island" Britain set apart from continental European machinations, only involving itself when absolutely necessary for urgent security reasons or to protect vital, mainly economic, interests (Saunders, 2018). initially as "balancer" in the Victorian heyday of Empire (Daddow, 2015) and, in the twentieth century, as a lone or one of a few "good" powers battling Europe's tyrannical dictators when they threatened to dominate the continental against British interests (Saunders, 2018).

While interconnected and overlapping in important ways, they are reported separately below for reasons of clarity. In line with previous findings on political oratory (von Bismarck, 2017; Charteris-Black, 2005, p. 26; see also-Finlayson, 2007) the data also indicated that metaphors did a lot of heavy lifting in constructing the in the construction of GlobalBritain $^{\mathrm{TM}}$ vision, so and-these became an equally important component of the $\underline{\text { codebook. Młn brief, metaphors are creative associations in language used to make "your }}$ hearers see things" by bringing "something fresh" to an audience's cognitive and emotional engagement with a given issue (Aristotle, 2012, p. 182 and p. 179). That political oratory "deals with future events" (Aristotle, 2012, p. 161) using evidence culled from history, makes journey metaphors particularly useful to the politicians who want to spell out where a country 
has come from, where it is, the dilemmas it faces and where they want to take it as navigatery devices. In the what was over the years 2016-2018 aninsurgent narrative-in-the-making in GlobalBritain ${ }^{\mathrm{TM}}, 5$ where concrete progress was always likely to be behind the need for a vision, we wold expect the metaphorical imagination to play an even more important role. As shown below, this proved to be case, with-journey, lightness/darkness and family metaphors were all in operation-. Having positioned the contribution and explained the method, the remainder of the article reports the findings. While all of these thematic elements and linguistic devices cross-cut in important ways, they are reported separately below for the purpeses of clarity.

The initial codebook was drawn up using the government's most influential purveyors of GlobatBritainTM discourse: Theresa May (2017a), Boris Johnsen (2017) and Liam Fox (2016). It was expanded - albeit not significantly - as further sources were brought to the 
table. ${ }^{6}$ The keywords signal what is important to a given speaker, but crucially they or their

\section{Policy architecture: the four pillars of GlobalBritain ${ }^{\mathrm{TM}}$}

Figure 1 sets down the proposed policy architecture for policy vision underpinning

GlobalBritain ${ }^{\mathrm{TM}}$.-Given the paramountey of economies to the Brexit debate has resulted in a national conversation "monopolised by the future trade and customs relationship" (Ricketts, 2018a), it is important to note that, away from specialized publications (for instance Kienzle and Hallams, 2016), the wider policy political, defence and security objectives have had less of an airing. The take-home theoretical point in this section is, therefore, that a sober discourse reading, away from the heat of Brexit minutiae, can shed light on themes and issues forgotten in the cut and thrust of a poliarized policy debate such as that instigated by Brexit.

[Figure 1 here]

The Pillar 1 priority for Global Britain isPillars 1 and 2 of GlobalBritain ${ }^{\mathrm{TM}}$ are about economics and the requirement to replace Britain's financial benefits from its expiring EU membership with new financial relationships with and beyond the EU. Top billing goes to Pillar 1 and "a bold and ambitious free trade agreement with the European Union" covering goods and services (May 2017a). This plays to a long tradition in the British Conservative Party and British European policy, where the politics of integration, especially concerning the loss of sovereignty involved, were hotly contested from Thatcher's September 1988 Bruges speech onward (Thatcher, 1988; Fontana and Parsens, 2015; Vail, 2015;). The British always preferred to construe European integration instrumentally as a source of nourishment for the domestic economy. The economic benefits of membership of the Single European Market (SEM), plus these aceruing to the City of London as a global financial hub, were reasens why even the EU's harshest detractors in Britain acquiesced in membership for solong. 
This-Discourse in pillarPillars 1 and 2 drew on an influential stand of ecenomic liberalism in Conservative Party thought, interweaving several propositions in support of an exceptionalist narrative (elaborated in Atkins, 2015) about seemed to be drawing on long established strands of Conservative Party thinking about Britain's role in the global political economy: first, that Britain was the architect ofbuilt the global free trade system in the nineteenth century; second, that free trade is a powerful force for good economically and politically; third, that Britain is uniquely well placed to benefit from free trade; fourth, that the EU's "highly regulated and expensive Single Market and Customs Union approach" inhibited Britain from achieving its "historic mission of supporting global free trade" (Stewart and Monteith, 2016, p. 2); and, finally, in terms of ethicality and imperial temperality, that the spread of free trade supplies the "a moral dimension to our mission" (Fox, 2017; see also Johnson, 2016). Intertextuality was in operation at this point, with Priti Patel (2017) name-checking Thatcher to argue of free trade that it is "one of the most dynamic forces for good in the world. It creates jobs, and fosters peace. It raises incomes and it unleashes the power of private enterprise. It changes individual lives, and by doing so it can transform entire economies."

Pillar 3 shifts from the hard power of economics to the softer power ofpolitics and culture, $\underline{\underline{7}}$ the aim being ing to create "a far-reaching science and innovation pact with the EU" (May, 2018c). This is to be anchored in "our academic and scientific communities...some of the world's best universities... And... cutting-edge research and innovation" (May, 2017a). May envisaged cooperation on space exploration, clean energy and medical technologies (May, 2017a), as fleshed out in her February 2018 Munich Security Conference speech (May, 2018b). Pillar 3 of GlobalBritain ${ }^{\mathrm{TM}}$ drew soft power comparative advantages that have been staples of elite foreign policy thinking for decades (see also Newman et al., 2017). In 1997, 
for example, Chancellor Gordon Brown (1997) eulogized the pioneering spirit and the "British Genius" (invoking George Orwell's wartime essay on socialism and the "English Genius") which Brown believed marked the country out for a leadership role in Europe and globally. May insinuated the same by referring to "the talents of our people" (May, 2018b; May, 2018c; May, 2018d). Johnson (2017) averred that British leadership would be exerted through the efforts of "inventors, scientists, business people, students and dreamers."

Pillar 4 deals with hard power politics,the hard power dimension of security cooperation between Britain and its European partners on "[cross-border] crime, terrorism and foreign affairs". The latter was geared towards containing "dangers presented by hostile states", not least Russia (May, 2017a), which under Putin was persistently accused of transgressing the norms and rules of international society, including through its "reckless use of chemical weapons on the streets of Britain by agents of the Russian GRU [Russian military intelligence]" (May, 2018c). May (2017d) wanted practical measures around law enforcement and intelligence sharing, formalised in "a treaty between the UK and the EU.'The goal, according to Davis (2017b), was "a strategic partnership that allows us to tackle the full range of threats we face". Taken togetherBetween the four pillars of GlobalBritain ${ }^{\mathrm{TM}}$ tell us what the government wanted from its international relationships after Brexit, prolonging decades-worth of thinking on how to secure British interests and promote its values in the global arena (Gilmore, 2014; Daddow, 2015a). The next section reports how the policy proposals were framed through an investigation into the narrative underpinnings of GlobalBritain ${ }^{\mathrm{TM}}$,

\section{GlobalBritain"}

As explained in the methods section, to map-GlobalBritainTM's discursive terrain is to consider it as "a coherent and comprehensive set of representations" (Todd, 2016, 23; 
emphasis in original), revolving around (ibid., citing Hansen; and agreeing with Daddow, using representative illustrations from the text data.

\section{Othering via differentiation Self and Other}

Othering was achieved by comparing and contrasting "British" identity, interests and values with those of its "European" neighbours, pointing out elements of overlap and difference. It is a fact, said May, that Britain and Europe "share common interests and values and so much else” (May, 2017c), making Britain, in Johnson's words, “one of the great quintessential European nations" (Johnson, 2017; see also Davis, 2017a). The unavoidable reality of existing in a shared geographic space had has encouraged the build-up of a dense web of cultural and commercial ties over centuries, or "lived, shared experiences"'"centuries-old shared cultural, social and economic ties that exist between us" (Davis,

2017b). This observation anchored one of May's most common soundbites (2017d): “We may be leaving the European Union, but we are not leaving Europe.". May drew on both Labour's internationalism (May, 2017c) as well as thinking more familiar to Conservatives from Thatcher's Bruges speech onward (Thatcher, 1988; Daddow, 2013) that: "We are a European country - and proud of our shared European heritage” (May, 2017a). Britain's values of "peace, democracy, human rights and the rule of law" (May, 2017d; May, 2018b) were sometimes presented as unique to Britain, at other times not specific to Britain, whichunique: "is not the only member state where there is a strong attachment to accountable and democratic government, such a strong internationalist mindset, or a belief that diversity within Europe should be celebrated" (May, 2017a).

All tThis said, the government believed that whatever historico-cultural affinities Britain shared with "Europe", it did not feel sufficiently "EU" to remain embedded in the organizationthe people had spoken in the referendum. Davis explained (2016) that Britain 
always saw the EU "differently" from its "European neighbours" because of different historical trajectories and "that has been one of the problems". Johnson (2016) concurred that the referendum result proved that the British could never "endorse the finalité politique of the EU" because it embodied a cornucopia of differences from the British way of "doing" governance:

Our political traditions are different. Unlike other European countries, we have no written constitution, but the principle of Parliamentary Sovereignty is the basis of our unwritten constitutional settlement. We have only a recent history of devolved governance.... and we have little history of coalition government (May 2017a; see also May, 2017b) .

One of the stated causes of the differentiation between "Europe" on the one hand and "Britain" on the other, was Britain's status of an island cut adrift from mainland Europe by the English (not British)Channel, opening the way to consider the spatial elements ofity the discursive construction of GlobalBritain ${ }^{\mathrm{TM}}$ discourse.

\section{Spatiality}

Mobilizing Britain's island geography prompted the producers of GlobalBritain ${ }^{\mathrm{TM}}$ prompted discourse to imagine "Europe" as an inconvenient or even hostile outlet for the expression of Britishness, driving a further wedge between the two imagined entities of "Britain" and "Europe". ${ }^{8}$ It is evident that Henrietta Marshall's famous 1905 school history textbook, Our Island Story, has had a strong hold over the national historical imaginary back to Victorian

\footnotetext{
${ }^{8}$ The imposition of Conservative interpretations of Englishness onto UK foreign policy and GlobalBritain ${ }^{\mathrm{TM}}$ discourse is beyond the remit of this article, but see (Kumar, 2003; Marquand, 2009; Vail, 2015)., suffice to say it further weakens the resonance of the narrative in Remain-voting countries such as Scotland.
} 
times (see Daddow, 2011; Brocklehurst, 2015; Wellings, 2018). Its account of English and British history has sustained two important spatializing narratives that surfaced in the 2016 membership referendum campaign and, later, and after, now fuelling GlobalBritain ${ }^{\mathrm{TM}}$ 's spatializing dimensions.

First, the requirement to uphold a loosely defined notion of British "sovereignty" (Ichijo, 2008; Todd, 2016) in the face of sovereignty-degrading practices in the EU (Thatcher, 1988). This was exemplified in theMay's claim that, after Brexit, Britain would be “in control of its own destiny once again [as in pre-1973, when it joined the European Community]" (May, 2017, emphasis added). This “control" purportedly extends over a variety of policy areas such as national borders, immigration numbers (Davis, 2016) and national security (Davis, 2017a). The second important spatializing narrative has been the perceived imperative to uphold a historically constituted sense of "traditional" (preCommunity entry) British identity in the face of "centralizing" tendencies in the maligned "Brussels" institutions, especially those downloaded from the European Commission and other institutions staffed by what are described as unelected "bureaucrats". In this Thatheerite vein,-May (2017a) said her biggest problem $\underline{s}$ with the EU wereas its "supranational institutions" (May, 2017a) thatit "struggled to deal with the diversity of its member countries and their interests. It bends towards uniformity, not flexibility." And third, as David Marquand has shown (2009, pp. 11 12), the historically constituted narrative of which proclaims the istand people to be a 'providential nation', 'uniquely freedom loving, and at the same time uniquely oceanic and uniquely imperial'.

The political implications of these spatializing narratives were clearly articulated by May in the Florence speech (2017d), where she suggested that because Britain was ef being geographically separate from mainland Europe, "the European Union never felt to us like an integral part of our national story in the way it does to so many elsewhere in Europe". After 
1945, GlobalBritain ${ }^{\mathrm{TM}}$ enthusiastsentrepreneur remarked, Britain's international journey had taken on a qualitatively different character from that of "core (integrationist) Europe". As Johnson put it, a "group of European countries" integrated regionally, while Britain and the US "had a different approach" (Johnson, 2016), carrying out a global mission as part of the post-war "Big Three" and, later "Big Five" UN powers that haves "defined the modern world" (May, 2017b), as well as being "present at the creation" of the North Atlantic Treaty Organization (NATO) as the irredeemable guarantor of European security (on Brexit and NATO see Dunne and Webber, 2016). Summing up the "exceptionalist" element of this discourse, Fox (2016) reflected that the British story was one of triumph against all odds: "--A small island perched on the edge of Europe became the world's largest and most powerful trading nation"-' (see also Davis, 2016; Fox, 2017). Britain's national trajectory, he implied, had simply been out of step with Europe's, and Brexit was the practical realization of that "fact" of international life.

\section{Temporality}

The post-Brexit direction of Britain's journey through international history was captured in a series of lightness/darkness metaphors representing Britain as a place of progress and enlightenment in contrast to the EU's zone of "backwardness and intransigence" (Todd, 2016, p. 31). Outside the EU, the framing went, Britain's "future is bright" (May, 2018c) because it could once more operate as an international "beacon" when it regained its status as an "independent trading nation" (Fox, 2016; see also Singham, 2017, pp. 3-4). ${ }^{9}$ The assertion that Britain could resist any Brexit-induced decline by operating as a "beacon for good for the world" also appeared in the Global Britain report (Stewart and Monteith, 2016, pp. 15-16 and

\footnotetext{
${ }^{9}$ The marked use of the word "beacon" to describe Britain's international "character" evokes the "Britain "standing alone in 1940" frame supported by a "lightness" metaphor, showing the overlapping nature of spatiality, temporality and ethicality, all of which can be captured in single words or metaphors.
} 
18). Other examples of lightness/darkness metaphors ef the light dark, semi religieus (2017c) that in the 2016 referendum the British people "fixed their eyes on that brighter future and chose a bold, ambitious course"; second, May (2017a) and Davis's (2016) (2017a) deseription of Britain beingassertions that Britain was on a journey to "a brighter future for our country" or "a brighter and better future" respectively, one in which it could "make the most of the opportunities ahead"; fourth, Fox's (2016) reflections on creating a "bright future", one not to be "darkened by the shadows of [implicitly EU] protectionism"; and finally, Johnson's (2017) concern that Britain not end up living out its days “in some dingy ante-room of the EU", which as May surmised (May, 2017a) would place Britain in a kind of "permanent political purgatory".-

\section{Ethicality}

Ethicality shone through whenever Britain was personified, as frequently it was, as "by instinct and histery a great global nation" (May, 2017b). We have alse seenWe saw previously that the idea moral judgements around the concept of Britain rediscovering lost or repressed "freedom" was an important constituent of GlobalBritain" ${ }^{\mathrm{TM}}$ discourse. It was encapsulated in allusions, first, to bothEthicality around Britain as anthe exceptional nation with a unique contribution to make to global politics was, therefore, found to reside inand, second, metaphors depictiøngs Britain as a prisoner returning to his/her former life following an unhappy period of incarceration inside the EU. This echoed Eurosceptic discourse that gained popularity around the time of the debate over the EU's Constitutional Treaty in 2004 (later the Lisbon Treaty), the Daily Mail arguing that EU member states were "hopeless captives of an all-encompassing, antidemocratic bureaucracy with a life of its own" (cited Ichijo, 2008, p. 79). In contrast, the EU was characterized as a "corpse” (Mason, 2012) a group of "losers" making a deadweight bloc in decline, holding Britain back. Nothing was 
more unpalatable to pro-Brexit politicians than "staying shackled to the EU" because it portended only further "national humiliation" (Fysh, 2018) or the realization of "vassal status" (Jacob Rees-Mogg cited Clegg, 2018) as a "colony” of the EU (Johnson, 2018).

In GlobalBritain ${ }^{\mathrm{TM}}$ discourse, the cascading metaphors around darkness/lightness and family underscored the righteousness of the journey on which Britain had embarked with Brexit. On leaving its prison, GlobalBritain ${ }^{\mathrm{TM}}$, said, Britain could ence againonce more “embrace the world" after Brexit (May, 2017a), a figure of speech operating at the nexus of spatiality and ethicality. May went big on the word "embrace" throughout her speeches (May, 2017c); it was also used several times in the report by the Legatum Institute (Stroud, 2017; Singham et al., 2017, p. 4). "Embrace" has two connotations: to accept something enthusiastically, or to hold someone closely in one's arms as a sign of affection. While both are poignant, the latter is particularly especially resonant in the context of GlobalBritain ${ }^{\mathrm{TM}}$ for two reasons. First, it suggests that the EU was preventing Britain expressing its "higher moral loyalty" to the Commonwealth and US, arising from "ties of family, kinship and history" (May, 2017b). Second, it establisheds the Commonwealth, US and Anglosphere as better more aligned than was the EU for the fulfilment of British interests, values via the enactment of its global leadership role.behind Britain's "determination to lead a race to the top in global standards" (Davis, 2017a).

There were said to be fewer or no such problems with these alternative outlets for the exertion of British agency in the global arena. As Kenny and Pearce suggest (2018, pp. 164 and 169), returning to the Commonwealth and former settler colonies of the Anglosphere (Hannan, 2014), would embody a return to "familiar" outlets for the expression of Britain's international agency. The Anglosphere has always occupied a distinctive role in the Conservative political imagination (Wellings and Baxendale, 2015). It is the name given to the core five countries in the Commonwealth (UK, Canada, Australia, New Zealand and the 
US) with which Britain is said to share a number of defining features: "liberal market economies, the common law, parliamentary democracy, and a history of Protestantism" (Kenny and Pearce, 2018, pp. 3-5; Vucetic, 2011). In contrast to the wedges driven by GlobalBritain ${ }^{\mathrm{TM}}$ advocates between "Britain" and "Europe", through Brexit, Britain and the EU would be negotiating a "partnership" between "neighbours" (May, 2018c). They would not be "embracing" but working pragmatically-and technocratically, "hand in hand" (May, 2017d; emphasis added). In sum, the "deep and special partnership" with the EU wasis, however, said implied to be less meaningful to British interests, self-identity and sense of its place in the worldBritain than the Commonwealth or the "special relationship" with the US, in July 2018 elevated by Trump on his visit to Britain as "the highest level of special" (Walker, 2018).

\section{Conclusions}

This article interpret GlobalBritain ${ }^{\mathrm{TM}}$ by using discourse analysis to unpack the two staple ingredients of foreign policy visions: the policies states aim at through their external practices and the accompanying narrative that frames and justifies those national policy choices to domestic and global audiences. On the policy side, the text data suggests that GlobalBritain ${ }^{\mathrm{TM}}$ continues the "pragmatic" tradition in British foreign policy, themed around the dogged pursuit of vital British economic and security interests through the exercise of its hard and soft power capabilities. This may seem surprising given the scale of the rupture in Britain's international relationships wrought about by Brexit. It makes more sense when it is recognized that continuity of grand strategy, occasionally requiring tactical recalibration, is ultimately what has animated British foreign policy for decades if not centuries (Bourne, 1970; Black, 2000). In a very real sense, the dominant GlobalBritain ${ }^{\mathrm{TM}}$ narrative evokes that surrounding Britain's applications and entry to the European Communities in 1973, which 
$\underline{\text { were sold as a change of tactic to achieve higher strategic ambitions, including a global }}$ "leadership" role (Daddow and Gaskarth, 2014). In a recent article in the pages of this journal, Paul Beaumont (2017, p. 380) argued that the saliency of Euroscepticism increased in UK polities over the last three decades around an influential consensus that "EU membership is especially threatening to Britain's historical narrative of the self". As the phrasing suggests, this was as much a narrative problem for pro Europeans, as it was an empirical of demonstrating the "facts" of what Britain did in/for the EU, and conversely what the EU did in/for Britain (see Daddow and Oliver, 2016). This article corroborated Beammont's argument about the importance of identity to an understanding of both the "why" and "how" of Brexit, by showing that GlobalBritainTM discourse is a bricolage of spatial, temporal and ethical propositions about Britain, its identity and role in the world, constructed against a malign "European" Other across the English Channel. This narrative construction was circulating before Brexit, but after 2016 was laced with Conservative Euroscepticism that brought the Othering practices more abruptly and bluntly to the fore.

The above findings on this vision in-the-making also give us the analytical tools for evaluating what might make GlobalBritain ${ }^{\mathrm{TM}}$ a "success". Obviously a "successful" Brexit will be key but that itself is a political judgement and one that will be helped by GlobalBritain TM taking hold as an accepted narrative about Britain's "new" role in the world. The questions future research needs to address to assess the effectiveness of this foreign policy vision are, therefore:The above discussion atse-suggests that the discourse method can be deployed as a tool of critical policy evaluation, because it is parsimonious and avoids overt jargonizing, which means it can easily "travel" across academic fields (connecting discourse theorists with foreign policy analysts) and from academia to policy (Cairney and Oliver, 2018; Craig, 2019). The requirement for an analytieal toolkit for dealing with politicians' respenses to current policy dilemmas is evident. British foreign policy makers have long 
avoided scrutinising the habits of thought and practice on which they base their decisions,

(ii) Do domestic stakeholders they believe GlobalBritain ${ }^{\mathrm{TM}}$ promotes vital British interests? fundamental British values? (iii) How has GlobalBritain ${ }^{\mathrm{TM}}$ been marketed internationally using public diplomacy at the UN (adding to Gifkins et al., 2019), ambassadorial speeches and the practices of the main government departments? (iv) Where have we seen "resistance" or "rival" narratives and what effect have they had in influencing the reception of the central narrative? And perhaps most crucially Underlying all this is the most vital question of all: (iv) one that outlasts the May government, get implemented institutionally and last,, or is it government (on narrative as a tool of policy evaluation see Craig, 2019)? As with so much around Brexit, the future remains uncertain. But knowing where to look and how to let the evidence "breathe", scholars should be able to contribute to informed conversations about the most vexed questions surrounding Brexit and Britain's future world role.

\section{References}

Aristotle. (2012). The art of rhetoric. London: Collins Classics.

Atkins, J. (2015). (Re)imagining Magna Carta: Myth, metaphor and the rhetoric of

Britishness. Parliamentary Affairs, 69(3), 603-620.

Austin, J. L. (1975). How to do things with words, $2^{\text {nd }}$ edn. Eds J.O. Urmson and M. Sbisà. Cambridge, MA.: Harvard University Press.

Ankersmit, F. R. (2001). Historical representation. Stanford, CA: Stanford University Press. 
Beaumont, P. (2017). Brexit, retrotopia and the perils of post-colonial delusions. Global Affairs, 3(4-5): 379-390.

Beech, M. (2011). British Conservatism and foreign policy: Traditions and ideas shaping Cameron's global view. British Journal of Politics and International Relations, 13(3), 348363.

Bevir, M. and Daddow, O. (2015). Interpreting foreign policy: national, comparative, and regional studies. International Relations, 29(3), 273-287.

Bevir, M., Daddow, O. and Hall, I. (Eds). (2014). Interpreting global security. London: Routledge.

Bevir, M., Daddow, O. and Schnapper, P. (2015). Introduction: Interpreting British European policy. Journal of Common Market Studies, 53(1), 1-17.

Black, J. (2000). A system of ambition? British foreign policy 1660-1793. London: Sutton.

Blagden, D. (2017). Britain and the world After Brexit. International Politics, 54(1), 1-25.

Blagden, D. (2018). Two visions of greatness: Roleplay and Realpolitik in UK strategic posture. Foreign Policy Analysis. Advance online publication.

https://doi.org/10.1093/fpa/ory011 
Bourne, K. (1970). The Foreign Policy of Victorian England 1830-1902. Oxford: Oxford University Press.

Bratberg, Ø. (2011). Ideas, tradition and norm Entrepreneurs: Retracing guiding principles of foreign policy in Blair and Chirac's speeches on Iraq. Review of International Studies, 37(1), 327-348.

British Foreign Policy Group. (2018, 16 April). The UK and the Commonwealth: where are we at and where can we go?. Retrieved from http://bfpg.co.uk/wpcontent/uploads/2018/04/BFPG-Report-COMMONWEALTH-APR-2018.pdf

Broad, M. and Daddow, O. (2010). Half remembered quotations from mostly forgotten speeches: The limits of Labour's European policy discourse. British Journal of Politics and International Relations, 12(2), 205-222.

Brocklehurst, H. (2015) Educating Britain? Political literacy and the construction of national history. Journal of Common Market Studies, 53(1), 52-70.

Brown, G. (1997, 20 May). Speech, 'Exploiting the British Genius’. Retrieved from http://webarchive.nationalarchives.gov.uk/20100402151057/http:/www.hmtreasury.gov.uk/speech_chex_200597.htm

Bruner, J. (1991). The narrative construction of reality. Critical Inquiry, 18(1), 1-21.

Cameron, D. and Panović, I. (2014). Working with written discourse. London: Sage. 
Casalicchio, E. and Rutter, T. (2018, 29 May). Foreign Office "must regain Whitehall power

on Brexit, trade and foreign aid". Civil Service World. Retrieved from:

https://www.civilserviceworld.com/articles/news/foreign-office-'must-regain-whitehall-

power-brexit-trade-and-foreign-aid'

Charteris-Black, J. (2005). Politicians and rhetoric: the persuasive power of metaphor.

Basingstoke: Palgrave Macmillan.

Chilton, P. (2004). Analysing political discourse: theory and practice. London: Routledge.

Clegg, N. (2018, 27 January). On Brexit, Jacob Rees-Mogg is right: Britain risks vassal status. Financial Times. Retrieved from https://www.ft.com/content/be44ff5a-028e-11e8$9 e 12-a f 73 e 8 d b 3 c 71$

Cohen, R. (2017, 20 January). Theresa May’s “-Global Britain”'- is Baloney. The New York Times. Retrieved from https://www.nytimes.com/2017/01/20/opinion/theresa-mays-globalbritain-is-baloney.html

Daddow, O. (2011). New Labour and the European Union: Blair and Brown's logic of history. Manchester: Manchester University Press.

Daddow, O. (2013). Margaret Thatcher, Tony Blair and the Eurosceptic Tradition in Britain. British Journal of Politics and International Relations, 15(2), 210-227. 
Daddow, O. (2015a). Constructing a "-great"- role for Britain in an age of austerity:

Interpreting Coalition government foreign policy, 2010-2015. International Relations, 29(3), 303-318

Daddow, O. (2015b). Interpreting the outsider tradition in British European policy speeches from Thatcher to Cameron. Journal of Common Market Studies, 53(1), 71-88.

Daddow, O. and Gaskarth, J. (2014). From value protection to value promotion: Interpreting British security policy'. In M. Bevir, O. Daddow and I. Hall (Eds). Interpreting Global Security (pp.73-91). London: Routledge.

Dale, I. (2017, 6 March). Former Indian Minister: "Empire 2.0 will go down like a lead balloon in India". LBC Radio. Retrieved from http://www.lbc.co.uk/radio/presenters/iaindale/empire-20-will-go-down-like-a-lead-balloon-india/

Davis, D. (2016, 2 October). Speech at Conservative Party Conference. Retrieved from: https://www.politicshome.com/news/uk/political-parties/conservativeparty/news/79518/read-full-david-davis-speech-conservative

Davis, D. (2018a, 20 February). Speech on the future economic partnership. Retrieved from: https://www.gov.uk/government/news/david-davis-foundations-of-the-future-economicpartnership-speech

Davis, D. (2018b, 6 June). Speech on the future security partnership. Retrieved from: https://www.gov.uk/government/news/david-davis-speech-on-the-future-security-partnership 
Devetak, R. (1995). Incomplete States: Theories and Practices of Statecraft. In J. Macmillan and A. Linklater (Eds). Boundaries in Question: New Directions in International Relations (pp. 19-39). London: Pinter.

Diamond, P. (2008). Shifting alliances: Europe, America and the future of Britain's global strategy. London: Politico's.

Dickens, C. (1970). Dombey and Son. London: Penguin.

Dunne, D. H. and Webber, M. (2016). The UK, the European Union and NATO: Brexit's unintended consequences. Global Affairs, 2(5), 471-480.

Foreign Affairs Committee. (2018a). Global Britain and the 2018 Commonwealth Summit, Seventh report of session 2017-19 (5 April). Retrieved from https://publications.parliament.uk/pa/cm201719/cmselect/cmfaff/831/831.pdf

Foreign Affairs Committee. (2018b). Global Britain: Sixth report of session 2017-19 (12 March). Retrieved from https://publications.parliament.uk/pa/cm201719/cmselect/cmfaff/780/780.pdf

Foreign and Commonwealth Office. (2018a, 21 March). Foreign Secretary announces 250 new diplomatic roles and ten new sovereign missions overseas. Retrieved from https://www.gov.uk/government/news/foreign-secretary-announces-250-new-diplomaticroles-and-ten-new-sovereign-missions-overseas 
Foreign and Commonwealth Office. (2018b, 13 June). Global Britain: delivering on our international ambition. Retrieved from https://www.gov.uk/government/collections/globalbritain-delivering-on-our-international-ambition

Finlayson, A. (2007). From beliefs to arguments: Interpretive methodology and rhetorical political analysis. British Journal of Politics and International Relations, 9(4), 545-563.

Fontana, C. and C. Parsons. (2015). “--One woman's prejudice””-: did Margaret Thatcher cause Britain's anti-Europeanism? Journal of Common Market Studies, 53:1, 89-105.

Fox, L. (2016, 29 September). Speech on free trade. Retrieved from https://www.gov.uk/government/speeches/liam-foxs-free-trade-speech

Fox, L. (2017, 9 March). Speech at Commonwealth Trade Ministers meeting. Retrieved from https://www.gov.uk/government/speeches/commonwealth-trade-ministers-meeting-towardsa-free-trading-future

Fysh, M. (2018, 23 April). Staying shackled to the EU, as the CBI wants, would be a national humiliation. Telegraph. Retrieved from

https://www.telegraph.co.uk/politics/2018/04/23/staying-shackled-eu-cbi-want-wouldnational-humiliation/ 
Gaskarth, J. (2006). Discourses and ethics: The social construction of British foreign policy. Foreign Policy Analysis, 2(4), 325-341.

Gaskarth, J. (2013). British foreign policy. Cambridge, UK: Polity Press.

Gifford, C. (2014) The making of Eurosceptic Britain, $2^{\text {nd }}$ edn. London: Routledge.

Gifkins, J., Jarvis, S. and Ralph, J. (2019). Global Britain in the United Nations. UNA-UK.

Retrieved from https://www.una.org.uk/file/13085/download?token=cl0pgYF-

Gilmore, J. (2014). The uncertain merger of values and interests in UK foreign policy. In T. Edmunds, J. Gaskarth and R. Porter (Eds). British Foreign Policy and the National Interest: Identity, Strategy and Security (pp. 23-42). Basingstoke: Palgrave Macmillan.

Grob-Fitzgibbon, B. (2016) Continental drift: Britain and Europe from the end of empire to the rise of Euroscepticism. Cambridge, UK: Cambridge University Press.

Gurău, C. and Ayadi, N. (2011). Political communication management: The strategy of the two main candidates during the 2007 French presidential elections. Journal of Communication Management, 15(1), 5-22.

Hagan, J.D. and Rosati, J.A. (1994). Emerging issues in research on foreign policy restructuring. In J.A. Rosati, J.D. Hagan and M.W. Sampson III (Eds). Foreign policy restructuring: How governments respond to global change (pp. 265-279) Columbia, SC: University of South Carolina Press. 
Hall, J.A. (1993). -Ideas and the social sciences’', in J. Goldstein and R.O. Keohane (eds), Ideas and foreign policy: Beliefs, institutions and political change (pp. 31-54). London: Cornell University Press.

Hannan, D. (2014, 2 March). The Anglosphere is alive and well, but $i$ wonder if it needs a better name. Telegraph. Retrieved from http://blogs.telegraph.co.uk/news/danielhannan/100261784/the-anglosphere-is-alive-andwell-but-i-wonder-whether-it-needs-a-better-name/

Hansen, L. (2006). Security as practice: discourse analysis and the Bosnian War. London: Routledge.

Hemmings, J. (2016, 4 July). What kind of foreign policy and security posture should a postBrexit Britain adopt?', RUSI Commentary. Retrieved from https://rusi.org/commentary/whatkind-foreign-policy-and-security-posture-should-post-brexit-britain-adopt

Hill, C. and Beadle, S. (2014, March). The Art of attraction: soft power and the UK's role in the world. London: British Academy.

Hirsch, A. (2018, 17 April). What is the Commonwealth if not the British Empire 2.0?'?, Guardian. Retrieved from https://www.theguardian.com/commentisfree/2018/apr/17/commonwealth-british-empirebritain-black-brown-people 
Honeyman, V. (2017). From liberal interventionism to liberal conservatism: The short road in foreign policy from Blair to Cameron. British Politics, 12(1), 42-62.

Hopf, T. (2002). Social construction of international politics: Identities and foreign policies, Moscow, 1955 and 1999. Ithaca, NY: Cornell University Press.

Ichijo, A. (2008). The balancing act: National identity and sovereignty for Britain in Europe. Exeter: Societas.

Johnson, B. (2016, 2 December). Speech at Chatham House. Retrieved from https://www.gov.uk/government/speeches/beyond-brexit-a-global-britain

Johnson, B. (2017, 3 October). Speech at Conservative Party Conference, Retrieved from https://blogs.spectator.co.uk/2017/10/boris-johnsons-conservative-conference-speech-fulltext/

Johnson, B. (2018, 16 July). The rest of the world believes in Britain. It's time that we did too', Daily Telegraph. Retrieved from https://www.telegraph.co.uk/politics/2018/07/15/restworld-believes-britain-time-did/./

Jørgensen, K. E. (2015). Discursively (de-)constructing European foreign policy: Theoretical and methodological challenges. Cooperation and Conflict, 50(4), 492-509.

Katzenstein, P.J. (1996). The culture of national security: Norms and identity-building in world politics. Columbia, NY: Columbia University Press. 
Kenny, M. and Pearce, N. (2018). Shadows of Empire: The Anglosphere in British politics. Cambridge: Polity Press.

Kienzle, B. and Hallams, A. (2016). European security and defence in the shadow of Brexit. Global Affairs, 2(5), 465-469.

Kirby, W. (2018, 13 January). David Davis snubbed: fears Brexit chief being forced out of

EU talks. Daily Express. Retrieved from: https://www.express.co.uk/news/uk/904329/brexitnews-eu-uk-david-davis-olly-robbins-phase-two-talks-michel-barnier-dexeu

Kitchen, C. (2013). Constructing identity in British foreign policy towards Iran after 9/11 (Unpublished doctoral thesis). University of Sheffield, UK.

Klotz, A. and Prakash, D. (2008). Qualitative methods in International Relations: A pluralist guide. Basingstoke: Palgrave Macmillan.

Kubálková, V. (ed.) (2001). Foreign policy in a constructed world. London: Routledge.

Kumar, K. (2003). The making of English national identity. Cambridge: Cambridge University Press.

Leadsom, A. (2016, 4 July). I want to guide Britain to the sunlit uplands. Leadership speech, Spectator. Retrieved from https://blogs.spectator.co.uk/2016/07/want-guide-britain-sunlituplands-full-text-andrea-leadsoms-leadership-speech/ 
Lunt, N. (2005). A Note on Political Science and the Metaphorical Imagination. Politics, 25(2), 73-79.

Manners, I. and P. Murray. (2016). The end of a noble narrative? European integration narratives after the Nobel Peace Prize. Journal of Common Market Studies, 54(1), 185-202.

Marlow, J. (1997). Metaphor, intertextuality, and the post-war consensus. Politics, 17(2), $127-133$.

Marquand, D. (2009). 'Bursting with skeletons': Britishness after Empire. Political Quarterly, 78, 10-20.

Marsh, D. and McConnell, A. (2010). Towards a framework for establishing policy success. Public Administration, 88(2), 56483.

Martin, J. (2016). Capturing desire: rhetorical strategies and the affectivity of discourse.

British Journal of Politics and International Relations, 18(1), 143-160.

Mason, R. (2012, 26 October). Britain "-shackled to corpse"-- of EU, says Douglas Carswell. Telegraph. Retrieved from https://www.telegraph.co.uk/news/politics/9636417/BritainFormatted: No underline, Font color: Auto shackled-to-corpse-of-EU-says-Douglas-Carswell.html

Mason, R. (2017, 10 July). Australia ready to do post-Brexit trade deal - but EU comes first. Guardian. Retrieved from https://www.theguardian.com/politics/2017/jul/10/australia-readyto-do-post-brexit-trade-deal-but-eu-comes-first 
May, T. (2016, 2 October). Speech at Conservative Party Conference. Retrieved from http://press.conservatives.com/post/151239411635/prime-minister-britain-after-brexit-avision-of

May, T. (2017a, 17 January). Speech at Lancaster House. Retrieved from https://www.gov.uk/government/speeches/the-governments-negotiating-objectives-forexiting-the-eu-pm-speech

May, T (2017b, 26 January). Speech at Republican Party Conference. Retrieved from https://www.gov.uk/government/speeches/prime-ministers-speech-to-the-republican-partyconference-2017

May, T. (2017c, 27 January). Speech at World Economic Forum. Retrieved from http://uk.businessinsider.com/theresa-may-davos-speech-full-text-2017-1

May, T. (2017d, 22 September). Speech in Florence. Retrieved from https://www.gov.uk/government/speeches/pms-florence-speech-a-new-era-of-cooperationand-partnership-between-the-uk-and-the-eu

May, T. (2018a, 2 February). Business Forum Speech in Shanghai. Retrieved from https://www.gov.uk/government/speeches/pm-business-forum-speech-in-shanghai-2february-2018 
May, T. (2018b, 17 February). Speech at Munich Security Conference. Retrieved from https://www.gov.uk/government/speeches/pm-speech-at-munich-security-conference-17february-2018

May, T. (2018c, 2 March). Speech at Mansion House. Retrieved from https://www.bbc.co.uk/news/uk-politics-43256183

May, T. (2018d, 26 September). speech at UN General Assembly, 26 September. Retrieved from https://www.gov.uk/government/speeches/pm-speech-to-the-un-general-assembly-26september-2018

McCourt, D. (2014). Britain and world power since 1945: Constructing a nation's role in international politics. Ann Arbor, MI: University of Michigan Press.

Milliken, J. (1999). The study of discourse in International Relations: A critique of research and methods. European Journal of International Relations, 5(2), 225-254.

Mohdin, A. (2018, 18 July). The decision-making style that helps leaders survive can also thwart their legacy. Quartz. Retrieved from: https://qz.com/1328805/theresa-mays-closeddecision-making-style-is-a-big-gamble-with-brexit/

Mordaunt, P. (2018, 21 June). Speech at Chatham House. Retrieved from https://www.gov.uk/government/speeches/the-great-partnership-delivering-global-britain 
Mordaunt, P. (2019, 20 January). Speech at AIDSfree Cities Global Forum. Retrieved from

https://www.gov.uk/government/speeches/international-development-secretary-opens-

$\underline{\text { aidsfree-cities-global-forum }}$

Newman, H., Booth, S., Shankar A., Greer, A. and Scarpetta, V. (2017, April). Global

Britain: Priorities for trade beyond the European Union. Retrieved from the Global Britain website: https://docs.google.com/viewerng/viewer?url=http://openeurope.org.uk/wpcontent/uploads/2017/04/170424_Global-Britain-paper-FULL-VERSION-WITHOUT-

EMBARGO.pdf

O’Murchu, C. and Mance, H. (2017, 4 December). 'Legatum: the think-tank at intellectual heart of "hard" Brexit', Financial Times. Retrieved from

https://www.ft.com/content/fac8b53e-d840-11e7-a039-c64b1c09b482

Oliver, T. (2017). 'Never mind the Brexit? Britain, Europe, the world and Brexit', International Politics, 54(1), 519-532.

Olusoga, D. (2017, 19 March). Empire 2.0 is dangerous nostalgia for something that never existed', Guardian. Retrieved from https://www.theguardian.com/commentisfree/2017/mar/19/empire-20-is-dangerous-nostalgiafor-something-that-never-existed 
http://www.independent.co.uk/news/world-0/justin-trudeau-brexit-latest-news-uk-turn-

inward-g20-summit-canada-leave-eu-prime-minister-a7824561.html

Pamment, J. (2015). Putting the GREAT back into Britain: National identity, public-private collaboration and transfers of brand equity in 2012's global promotional campaign. British Journal of Politics and International Relations, 17(2), 260-283.

Patel, P. (2017, 10 March). Speech on Commonwealth trade. Retrieved from https://www.gov.uk/government/speeches/priti-patel-commonwealth-trade-speech

Pickard, J. and Mance, H. (2017, 18 September). Theresa May brings Brexit official Olly $\underline{\text { Robbins under her control. Financial Times. Retrieved from: }}$ https://www.ft.com/content/f8f7d6e6-9c67-11e7-8cd4-932067fbf946

Porter, P. (2018). Blunder: Britain's war in Iraq. Oxford: Oxford University Press.

$\underline{\text { Raab, D. (2018, } 1 \text { October). Speech at Conservative Party Conference. Retrieved from: }}$ $\underline{\text { https://brexitcentral.com/dominic-raab-speech-conservative-party-conference/ }}$

Rankin, J. (2018). ‘Jeremy Hunt rebuked by EU after Soviet prison comparison', Guardian, 1

October. Available from: Retrieved from

https://www.theguardian.com/politics/2018/oct/01/jeremy-hunt-draws-eu-ire-over-sovietprison-comparison-1Accessed 1 October 2018]. 
Renison, A. and Mandelson, P. (2018, 15 April). Can the Commonwealth provide Britain's trading future? Financial Times. Retrieved from https://www.ft.com/content/8aa19c96-3e3c11e8-bcc8-cebcb81f1f90

Ricketts, P. (2018๖, 6 May). Why Brexit means diminished British weight in the world', Prospect. Retrieved from https://www.prospectmagazine.co.uk/world/why-brexit-meansdiminished-british-weight-in-the-world

Rogers, J. (2017, 28 November). 'Global Britain' and the future of the British armed forces. Retrieved from The Henry Jackson Society website: http://henryjacksonsociety.org/wpcontent/uploads/2017/11/HJS-Global-Britain-and-the-Future-of-the-British-Armed-ForcesReport-2.0.pdf

Saunders, R. (2018, 19 December). 'Clap your hands if you believe in Brexit', Foreign Policy. Retrieved from https://foreignpolicy.com/2018/12/19/clap-your-hands-if-you-believein-brexit/

Schwartz-Shea, P. and Yanow, D. (2012). Interpretive research design: Concepts and processes. London: Routledge.

Seely, B. and Rogers, J. (2019). Global Britain: A twenty-first century vision. Retrieved from The Henry Jackson Society website: https://henryjacksonsociety.org/wpcontent/uploads/2019/02/HJS-Global-Britain---A-Twenty-first-Century-Vision-Report-A4web.pdf 
Shapiro, M.J. (1989). Textualizing global politics. In M.J. Shapiro and J. Der Derian (Eds). International/intertextual relations: Postmodern readings of world politics (pp. 11-22).

Lexington, MA.: Lexington Books.

Singham, S., Tylecote, R. and Hewson, V. (2017, November). The Brexit inflection point: The pathway to prosperity. Retrieved from Legatum Institute website:

https://britainsfuture.co.uk/documentation/the_brexit_inflection_point_the_pathway_to_pros perity.pdf

Slack, J. (2017, 17 January). Theresa's new free Britain. Daily Mail, 17 January. Retrieved from https://www.pressreader.com/uk/daily-mail/20170117/281479276113429

Staunton, D. (2018, 30 September). Brexit: Jeremy Hunt compares EU to prison and Soviet Union. Irish Times. Retrieved from https://www.irishtimes.com/news/world/uk/brexitjeremy-hunt-compares-eu-to-prison-and-soviet-union-1.3646873

Stewart, E. and Monteith, B. (2016, 30 September). Going global without delay: Leading the world to tariff-free trade. Retrieved from Global Britain website:

https://globalbritain.co.uk/wp-content/uploads/2016/12/GB-Soft-Copy-Going-global-withoutdelay-Body.pdf

Strong, J. (2018). Using role theory to analyse British military intervention in the Syrian civil war during David Cameron's premiership. British Politics. Advance online publication. https://doi.org/10.1057/s41293-018-00095-Z 
Stroud, P. (2017). Foreword. in S. Singham, R. Tylecote and V. Hewson. The Brexit inflection point: The pathway to prosperity. Retrieved from Legatum Institute website: https://britainsfuture.co.uk/documentation/the_brexit_inflection_point_the_pathway_to_pros perity.pdf

Todd, J. (2016). The UK's relationship with Europe: struggling over sovereignty.

Basingstoke: Palgrave Macmillan.

Usherwood, S. (2017, 15 December). What is Theresa May's decision making style? PSA

Blog. Retrieved from: https://www.psa.ac.uk/psa/news/what-theresa-mays-decision-making$\underline{\text { style }}$

Vail, M.I. (2015). Between one- nation Toryism and neoliberalism: The dilemmas of British Conservatism and Britain's evolving place in Europe. Journal of Common Market Studies, 53(1), pp. 106-122.

Von Bismarck, H. (2017, 13 November). War metaphors have no place in the Brexit debate. The Times. Retrieved from https://www.thetimes.co.uk/article/helene-von-bismarckwarmetaphors-have-no-place-in-the-brexit-debate-gtnstd5hr.

Vucetic, S. (2011). The Anglosphere: A genealogy of a racialized identity in international relations. Stanford, CA: Stanford University Press. 
Walker, P. (2018, 13 July). 'The highest level of special: Trump praises US relationship with UK. Guardian. Retrieved from https://www.theguardian.com/us-news/2018/jul/13/the-

highest-level-of-special-trump-praises-us-relationship-with-uk13

Wellings, B. (2016) ‘Our Island Story’: England, Europe and the Anglosphere Alternative. Political Studies Review. 14(3), 368-377.

Wellings, B. and Baxendale, H. (2015). Euroscepticism and the Anglosphere: traditions and dilemmas in contemporary English nationalism. Journal of Common Market Studies, 53(1), 123-139.

Wendt, A. (1999). Social theory of international politics. Cambridge, UK: Cambridge University Press.

Wetherell, M., Taylor, S. and Yates, S. (2009). Discourse as data: A guide for analysts. London: Sage.

White, H. (1975). Metahistory: The historical imagination in nineteenth-century Europe. Baltimore, MA: The Johns Hopkins University Press.

White, H. (1981). The value of narrativity in the representation of reality. In W.J.T. Mitchell (Ed.). On Narrative (pp. 1-23). Chicago, IL: The University of Chicago Press.

Wilson II, E.J. (2008). Hard power, soft power, smart power. The Annals of the American Academy of Political and Social Science, 616(1): 110-124. 
Yanow, D. (2000). Conducting interpretive policy analysis. London: Sage.

\section{Acknowledgements}

I am indebted to the two anonymous journal reviewers plus the following for their insightful comments on previous drafts: John Bew, Patrick Porter, Hannah Pembury and Ian Wash.

\section{Conflict of interest}

None

\section{Appendix: Coded speech}

Submitted separately

Table 1: Overview of main primary sources

Submitted separately

Figure 1: The Four Pillars of Global Britain

Submitted separately 